\title{
Simulation Tools Used at the Injection Mould Design
}

Peter Monka, Sergej Hloch, Andrej Andrej, Matej Somsak, Filip Murgas

Faculty of Manufacturing Technologies with the seat in Presov, TU Kosice, Sturova 31, 08001 Presov, Slovakia, E-mail: peter.monka@tuke.sk; sergej.hloch@tuke.sk; andrej.andrej@tuke.sk; matej.somsak@tuke.sk; filip.murgas@centrum.sk

The article deals with the basic steps of injection mould design. The goal of the research was the proposition of the mould form so to be achieved the minimum waste and the shortest time of both mould filling and product cooling. Studied mould component is intended to serve as a stopper in the automotive spotlight. The simulations were realized for three designed types of running system and for four versions of cooling system. Due to the design optimization, the pressures, originated inside the cooling system and inside the mould cavity during the injection moulding process, were also investigated. 3D model of the mould was created in Autodesk Inventor Professional software and then solidification of material was simulated in Autodesk Moldflow. On the basis of the best solution, real form was manufactured and placed into injection moulding machine Arburg Allrounder $320 \mathrm{C}$.

Keywords: design, simulation, injection moulding, running and cooling system, pressure, waste

\section{Acknowledgement}

This article originates with the direct support of Ministry of Education of Slovak republic by grants VEGA 1/0614/15, KEGA 013TUKE-4/2014 and KEGA 087TUKE-4/2015.

\section{References}

[1] BEHALEK, L., DOBRANSKY, J. (2013). Conformal cooling of the injection moulds, In: Applied Mechanics and Materials. Vol. 308 p. 127-132.

[2] FULEMOVA, J., REHOR, J. (2015). Influence of form Factor of the Cutting Edge on Tool Life during Finishing Milling, In: Procedia Engineering, p. 682-688.

[3] RESS, H., C. (2006). Selecting Injection Molds - Weighing Cost versus Productivity, Hanser Publishers

[4] MONKOVA, K. (2014) Virtual geometrical data definition of part with unspecified shape, Advanced Materials Research, 871, pp. 369-372.

[5] FULEMOVÁ, J., ŘEHOŘ, J. (2015) Influence of form factor of the cutting edge on tool life during finishing milling, Energz Procedia, Vol. 100, Issue C, p.682-688.

[6] HOLESOVSKY, F., NAPRSTKOVA, N., NOVAK, M. (2012). GICS for grinding process optimization, Manufacturing Technology, Vol. 12, No. 12, p. 22-26.

[7] PASKO, J. et al. (2010). Influence of technological parameters of die casting on qualitative properties of castings, In: Manufacturing engineering and technology, no. 1, p. 3-6.

[8] MARES, A., SENDERSKA, K., KOVAC, J. (2012). Data glove application in assembly, In: Transfer of inovations, no. 22 p. 133-137.

[9] ROSATO, D. et al. (2000). Injection Molding Handbook, 3rd ed. Kluwer Academic Publishers

[10] GOBAN, J. (2013) Optimization of mould cooling system for the plastic injection technology, Doctoral thesis, FMT TUKE, Presov

[11] DOBRANSKY, J., MIKUS, R., RUZBARSKY, J. (2013). Comparison of cooling variants by simulation software, In: Advanced Materials Research, Vol. 801 p. 75-80

[12] DOBRANSKY, J., BARON, P. (2010). Application of Computer Simulation in the Manufacture of Thermoplastic Products by Injection Molding, ICCEE 2010 3rd International Conference on Computer and Electrical Engineering proceedings, Chengdu, China p. 628-631

[13] KOVAC, J. et al. (2014). The impact of design parameters of a horizontal wood splitter on splitting force, In: Drvna industrija: znanstveni časopis za pitanja drvne technologije, Vol. 65, n. 4, p. 263-271.

[14] MONKOVA, K., HRIC, S. (2014). Optimization of injection moulding process from the view of cavity filling time and product cooling time, Applied Mechanics and Materials, 621, pp. 208-213. 
[15] FABIAN, M. et al. (2015). Use of Parametric 3D Modelling - Tying Parameter Values to Spreadsheets at Designing Molds for Plastic Injection, Manufacturing Technology, Vol. 15, No. 1, p. 24-31.

[16] PILC, J., DEMEC, P., CILLIKOVA, M. (2008). Construction of manufacturing machines, current trends, Mechanical Engineering, Vol.12, No. 11 p. 8-9.

[17] LEGUTKO, S. et al. (2014). Quality Evaluation of Surface Layer in Highly Accurate Manufacturing, Manufacturing Technology, Vol. 14, No. 1, p. 50-56.

[18] CESÁKOVÁ, I., ZETEK, M., SVARC, V. (2014). Evaluation of cutting tool parameters In: Procedia Engineering Vol. 69, p. 1105-1114.

Copyright (C) 2016. Published by Manufacturing Technology. All rights reserved. 